\title{
FISHERY RESOURCE POTENTIAL OF MANIMALA RIVER OF KERALA, INDIA
}

\author{
Mathews Plamoottil ${ }^{1}$ and G. Suvarnakumar \\ ${ }^{1}$ Asst. Professor in Zoology, Govt. College, Chavara, Kollam,Kerala \\ Principal, Govt. College, Uduma, Kasaragod, Kerala \\ Corresponding Author- mathewsplamoottil@gmail.com
}

ABSTRACT: Studies were conducted on abundance and diversity of ichthyofauna of Manimala River. Ninety seven fish species were collected from various locations of Manimala River. Species diversity, total number of species, fishery potential, percentage of different aspects of catches etc were taken into consideration.

KEYWORDS: Riverine resources, Ichthyofauna, Fish abundance, Species diversity

\section{INTRODUCTION}

The fish fauna of the freshwater environment shows considerable variations in genera and species when compared to estuarine and marine environment. Monitoring the occurrence of the species and their population has been the basis for assessing the effects of environmental impacts $^{1}$. Moreover it is the basic step in assessing the fishery resources and their management. Fish fauna of the rivers are harmfully affected by overfishing, habitat alteration, water pollution and changes in land use. Information on the abundance and species composition of the fish fauna may be helpful to have insight into various threats affecting the water bodies which lead to decline of species.

Various studies had been conducted on the abundance and dynamics of fish fauna of rivers of Kerala ${ }^{2,3,4}$. A detailed study on the patterns and process of fish assemblages in Periyar Lke valley system was undertaken by Arun $^{5}$ and in Vellayani Lake by Sandhya ${ }^{6}$.
No such studies were conducted in Manimala River. Hence it was felt necessary to undertake a detailed study on the fish abundance and potential in the River.

\section{MATERIALS AND METHODS}

Samples of fishes were collected from the selected twenty stations of the Manimala River using different types of fishing gears. Selection of these gears was based on its fishing efficiency in a running water body. At all stations fishes were caught using caste and gill net. After fishing, nets were brought to shore at once and entangled and gilled fishes were carefully taken out. Fishes were cleaned with water and kept in $10 \%$ formalin and are later taxonomically identified using authentic works.

\section{RESULTS AND DISCUSSION}

Total number of 97 fishes belonging to 11 orders, 33 families 57 genera and 97 species were obtained during the period of 
study from January 2011 to December 2011. Of the 11 orders, Cypriniformes became the largest order with 39 species of fishes, followed by Perciformes with 22 species and then Siluriformes with 21 species (Figure 1-4)

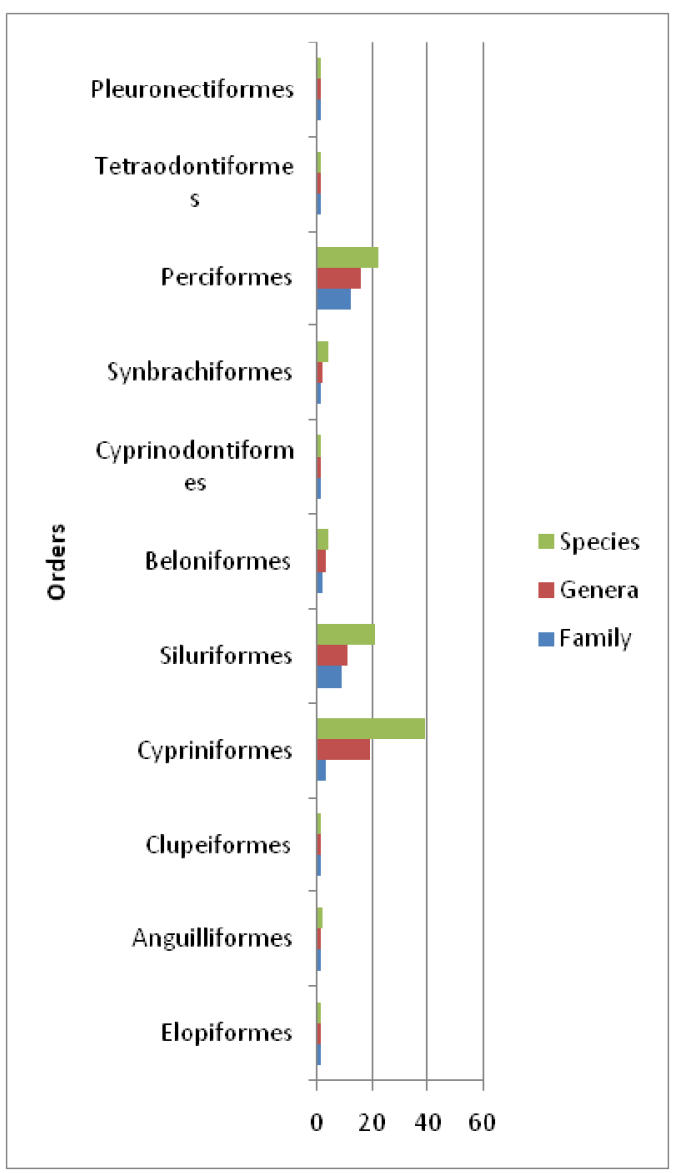

Fig.1. Systematic groups and species in Manimala River.

Many specimens of Megalops cypinoides were collected from low level regions and vey rarely from mid level regions; it is primarily a brackish water fish and might have ascended from Vembanad Lake. Anguilla bengalensis and Anguilla bicolor are found to be widely distributed in low level regions such as Manackachira and Kuttoor. They are believed to have medicinal values. Salmostoma boopis is a palatable small fish found mainly in the mid level regions. Barilius bakeri is abundantly found in all regions of the Manimala River; during the months of September and October it is caught in large quantities by Vattavala. Rasbora dandia was collected from the high level and mid level regions; it is not much valued as a food fish; but consumed by the local people. Amblypharyngodon melettina and A. microlepis are small edible fishes distributed in the mid level and low level regions of the River. They are important in the small meshed gill net fishery of the low level regions. Some fishermen are solely engaged in the Amblypharyngodon fishery. Cirrhina migala, C. cirrhosus, Catla catla, Labeo rohita, Labeo dussumieri and L. ariza are large to medium sized fishes found in middle and low level regions of the river. They are of major interest to fisheries. Many fishermen of Manimala River find their income from its fisheries.

Pangasinodon hypothalamus was collected from middle and low level regions of the river. Even though its number is less, it may grow to large size. Mystus heoki, M. menoni, $M$. indicus, $M$. keralai, $M$. canarensis, M. oculatus, M. gulio and $M$. malabaricus are found in various locations of the river. Some fishermen of the low 
level regions are solely engaged in the fishery of Mystus oculatus. Specimens of Ompok malabaricus were collected from all locations of the river; but $O$. bimaculatus were found to be restricted in some particular locations of the river. Hyporhamphus limbatus and $H$. xanthopterus were found to be distributed in middle and low level regions of the river; H. xanthopterus and Strongylura strongylura collected in the low level regions of the river might be ascended from Vembanad Lake.

Species Diversity: Greatest number of species were collected from Kallumkal; $43.3 \%$ of all fish species collected were from this low level region of the Manimala River; of the 97 species of fishes recorded from the river, 42 were present in Kallumkal; great species diversity of this place may be due to the fact that Pamba River merges with Manimala River at this place; so some fishes of the River Pamba may also be present here. Estuarine fishes of Vembanad Lake might also be ascended to this area. Manackachira is the second abundant area in species diversity. 40 freshwater fish species were recorded from this area. It formed $41.2 \%$ of the total species of the river. Generally low level regions showed greatest species diversity; middle level regions came next; high level regions were found to be poor in diversity of species. When fishing was done with gill nets Manackachira showed greatest species diversity (32 species; $33 \%$ ); west Venpala came to next place (31 species; $32 \%)$. When caste net was used 33 fish species $(34 \%)$ were collected from Kallumkal.

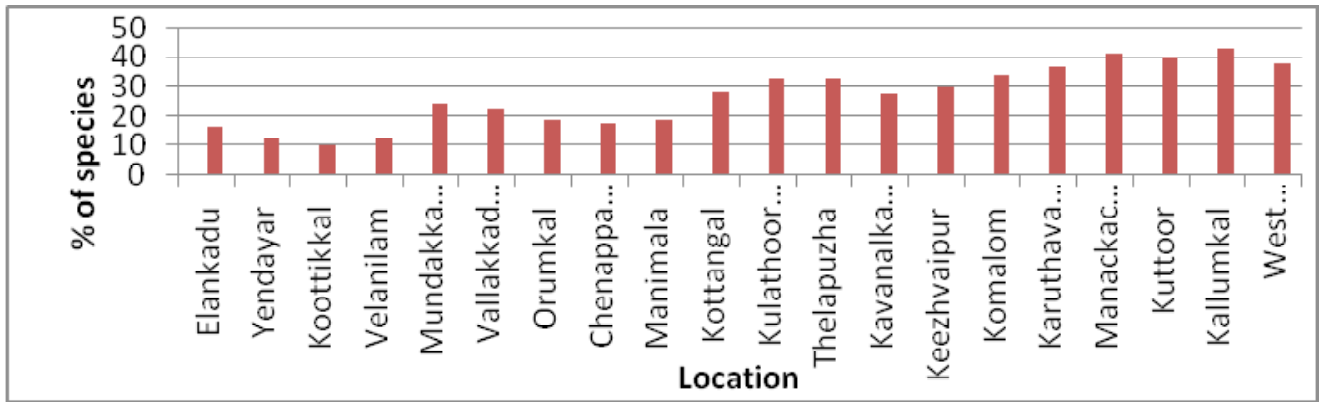

Fig. 2. Total no. of fish species collected from various locations of Manimala River using both gill net and caste net.

Total number of fishes collected: It was found that cast net is not an effective fishing gear in Manimala River. It is not used by professional fishermen; using cast net greatest number of fishes collected from
Manackachira; 250 fishes collected from here using cast net. It formed $3.3 \%$ of total fish collection using both gill net and cast net. Kuttoor came next with 216 fishes which formed $2.9 \%$ of the total catch. Cast 
net operation was found to be successful in Yendayar; here 205 fishes were caught (2.7\%). From Mundakkayam only $1.3 \%$ of fishes were collected using cast net. Due to lack of suitable sandy shore area, throwing of cast net was found to be a trying endeavor here. Gill nets were found to be an efficient gear in many places of the river.
Large scale fishing was carried in some places using gill net. $5.3 \%$ of fishes collected from Manackachira using this gear. West Venpala came to second with $3.9 \%$ fish collection. $3.8 \%$ fishes were collected from Kallumkal. Generally gill netting was successful in low level regions.

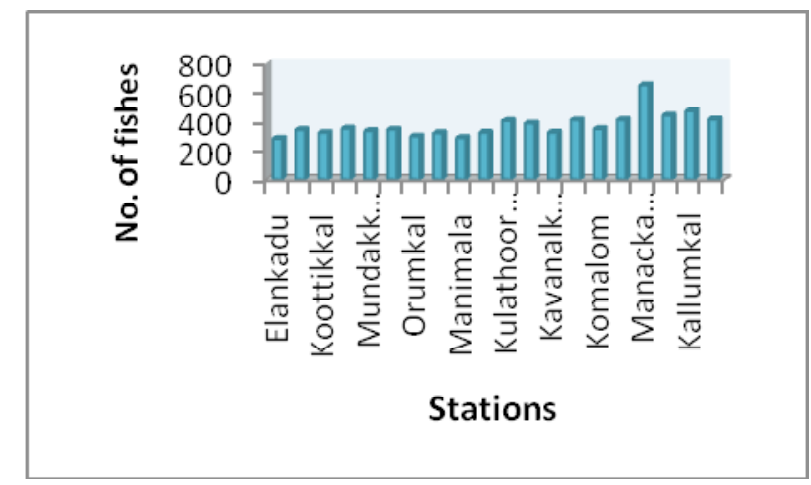

Fig. 3. Total number of fishes collected using both gill net and caste net.

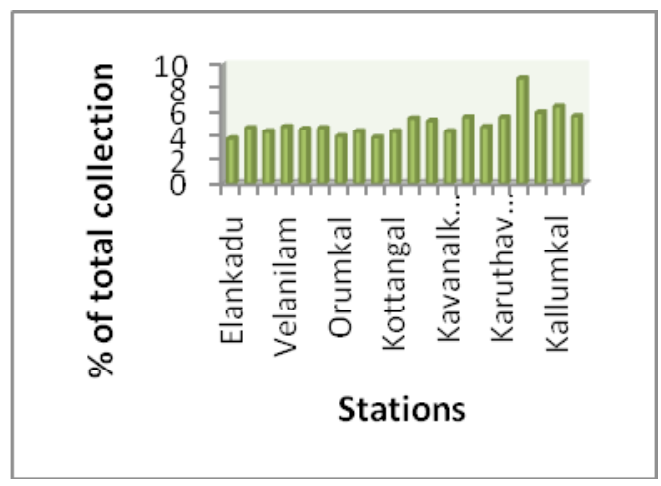

Fig. 4. Percentage of total number of fishes using both gill net and caste net.

Conclusion: Cypriniformes became the largest order with 39 species of fishes, followed by Perciformes with 22 species and then Siluriformes with 21 species. Greatest number of species was collected from Kallumkal; $43.3 \%$ of all fish species collected were from this low level region of the Manimala River; Manackachira is the second abundant area in species diversity. 40 freshwater fish species were recorded 
from this area. It formed $41.2 \%$ of the total species of the river. Kuttoor ranked third in species diversity; here 39 species were recorded which form $40.2 \%$ of the total species diversity. West Vempala, Karuthavadasserikkara and Komalom also showed greater species diversity. Generally low level regions showed greatest species diversity; middle level regions came next; high level regions were found to be poor in diversity of species. It was found that cast net is not an effective fishing gear in Manimala River. It is not used by professional fishermen; using cast net greatest number of fishes collected from Manackachira; 250 fishes collected from here using cast net. It formed $3.3 \%$ of total fish collection using both gill net and cast net. Kuttoor came next with 216 fishes which formed $2.9 \%$ of the total catch.

\section{ACKNOWLEGEMENT}

The authors acknowledge Principal,
Govt. College, Chavara for providing necessary facilities.

\section{REFERENCES}

1. Spellerberg, F.I., 1993. Monitoring ecological change. Cambridge University Press, Melbourne, Australia.

2. Arun, L.K., 1992. Niche segregation in fish communities of a south Indian river. $\mathrm{PhD}$ thesis. University of Kerala, pp. 196.

3. Easa, P.S \& S. C. Basha. 1995. A survey on the habitat and distribution of stream fishes in the Kerala part of Nilgiri Biosphere Reserve, KFRI research report No. 104. Kerala Forest research Institute, Peechi.

4. Easa, P.S. \& C.P. Shaji. 1996. Freshwater fishes of Pambar River, Chinnar Wild Life Sanctuary, Kerala, Journal of Bombay Natural History Society, 93 (2): 304 - 305.

5. Arun, L. K., 1997. Patterns and processes of fish assemblages in Periyar Lake- Valley system. KFRI research report No. 172. Kerala Forest research Institute, Peechi.

6. Sandhya, G., 2003. Structure and diversity of fish assemblages and their dynamics in Vellayani Lake. $\mathrm{PhD}$ thesis submitted to Kerala University. 